\title{
Experimental impacts of climate warming and ocean carbonation on eelgrass Zostera marina
}

\author{
Richard C. Zimmerman ${ }^{1, *}$, Victoria J. Hill ${ }^{1}$, Malee Jinuntuya ${ }^{1}$, Billur Celebi ${ }^{1}$, \\ David Ruble ${ }^{1}$, Miranda Smith ${ }^{1}$, Tiffany Cedeno ${ }^{1,3}$, W. Mark Swingle ${ }^{2}$
}

${ }^{1}$ Department of Ocean, Earth \& Atmospheric Sciences, Old Dominion University, 4600 Elkhorn Ave., Norfolk, VA 23529, USA

${ }^{2}$ Virginia Aquarium \& Marine Science Center, 717 General Booth Blvd., Virginia Beach, VA 23451, USA

${ }^{3}$ Present address: Marine Science Institute, University of California, Santa Barbara, CA 93106, USA

\begin{abstract}
CO}_{2}$ is a critical and potentially limiting substrate for photosynthesis of both terrestrial and aquatic ecosystems. In addition to being a climatewarming greenhouse gas, increasing concentrations of $\mathrm{CO}_{2}$ will dissolve in the oceans, eliciting both negative and positive responses among organisms in a process commonly known as ocean acidification. The dissolution of $\mathrm{CO}_{2}$ into ocean surface waters, however, also increases its availability for photosynthesis, to which the highly successful, and ecologically important, seagrasses respond positively. Thus, the process might be more accurately characterized as ocean carbonation. This experiment demonstrated that $\mathrm{CO}_{2}$ stimulation of primary production enhances the summertime survival, growth, and proliferation of perennial eelgrass Zostera marina from the Chesapeake region, which is regularly impacted by summer heat stress. The experiment also quantified the logarithmic response to $\mathrm{CO}_{2}$ in terms of shoot proliferation, size, growth and sugar accumulation that was fundamentally consistent with model predictions based on metabolic carbon balance derived from short-term laboratory experiments performed with other eelgrass populations from cool ocean climates and other seagrass species from tropical and temperate environments. Rather than acting in a neutral fashion or as an independent stressor, increased $\mathrm{CO}_{2}$ availability can serve as a quantitative antagonist to counter the negative impact of climate warming on seagrass growth and survival. These results reinforce the emerging paradigm that seagrasses are likely to benefit significantly from a high- $\mathrm{CO}_{2}$ world.
\end{abstract}

KEY WORDS: Climate warming · Ocean acidification · Eelgrass · Carbon balance · Photosynthesis . Temperature $\cdot \mathrm{CO}_{2}$

\footnotetext{
*Corresponding author: rzimmerm@odu.edu
}

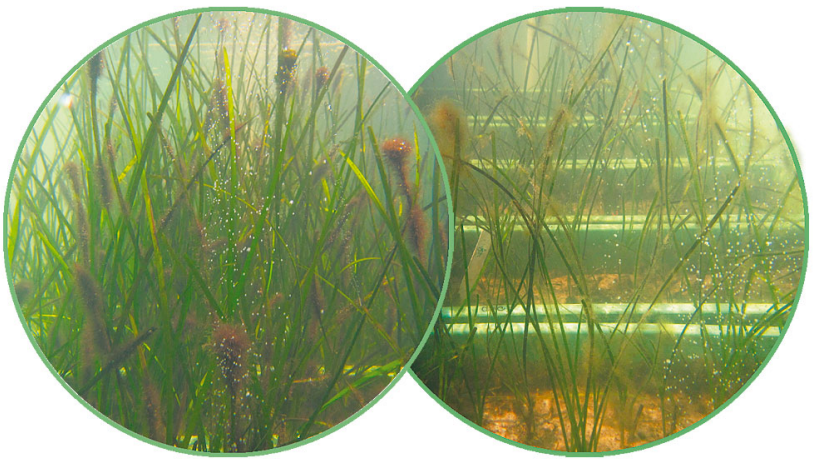

$\mathrm{CO}_{2}$ enrichment during a warm summer increases eelgrass density and shoot size (left) compared to ambient $\mathrm{CO}_{2}$ conditions (right) in experimental aquaria

Photos: Billur Celebi

\section{INTRODUCTION}

The global monthly mean $\mathrm{CO}_{2}$ concentration of the earth's atmosphere exceeded 400 ppm in 2016 (Dlugokencky \& Tans 2016) and appears to be increasing significantly faster than previously anticipated (IPCC 2013). Present-day concentrations are now higher than at any time in the last 40 million years (Pearson \& Palmer 2000). Not coincidentally, the earth's climate has warmed nearly $1^{\circ} \mathrm{C}$ since 1880, generating phenological changes in natural ecosystems including the progressively early occurrence of spring activities (budbreak, reproduction, migrant arrival), extended growing seasons (days above freezing), a delay in the onset of autumnal activities including outmigration, leaf coloring and abscission, and shifts in species range and commu-

() The authors 2017. Open Access under Creative Commons by Attribution Licence. Use, distribution and reproduction are unrestricted. Authors and original publication must be credited. 
nity composition (Walther et al. 2002, Cleland et al. 2007).

In addition to being a climate-warming greenhouse gas, $\mathrm{CO}_{2}$ is a critical and potentially limiting substrate for photosynthesis in both terrestrial and aquatic ecosystems. $\mathrm{CO}_{2}$ enrichment experiments with terrestrial plants have shown (1) enhanced carbon uptake, even in the presence of photosynthetic acclimation, (2) increased nitrogen and water use efficiencies, and (3) increased dark respiration, although the positive impacts on crop yield have been less than predicted (see review by Leakey et al. 2009 and references cited therein).

Similar to the impacts on terrestrial ecosystems, the increased concentrations of $\mathrm{CO}_{2}$ dissolved in the oceans of the world will elicit both negative and positive responses among organisms, ultimately potentiating ecological losers and winners. Organisms and ecosystems, including hermatypic corals and marine bivalves (e.g. oysters) and the reef structures they generate, as well as pelagic pteropods, to name but a few, are likely to be negatively impacted as calcification becomes energetically less favorable in an acidified ocean (Kleypas et al. 1999, 2006, Fabry et al. 2008). The dissolution of $\mathrm{CO}_{2}$ into ocean surface waters, however, also increases its availability for photosynthesis. Although many marine primary producers are predicted to exhibit very little response to ocean carbonation (Mackey et al. 2015), photosynthetic rates of several taxonomic groups, including nitrogen-fixing cyanobacteria (Hutchins et al. 2007), coccolithophores (Rivero-Calle et al. 2015) and the weedy chlorophytes Caulerpa spp. and Ulva spp. (Beer 1994, Hall-Spencer et al. 2008), as well as the highly successful and ecologically important seagrasses (Zimmerman et al. 1997, Invers et al. 2001, Jiang et al. 2010, Campbell \& Fourqurean 2013), have been shown to respond positively to increased $\mathrm{CO}_{2}$ concentrations.

The seagrass Zostera marina L. (eelgrass) is widely distributed on sandy shores and estuaries throughout the temperate Northern Hemisphere, where it plays an important role in sediment stabilization and habitat provision for many ecologically and economically important invertebrates and fish, and represents a significant blue carbon sink (Orth et al. 2006, McLeod et al. 2011). Positive long-term ( $>1$ yr) effects of dissolved aqueous $\mathrm{CO}_{2}$ concentration $\left(\left[\mathrm{CO}_{2(\mathrm{aq})}\right]\right)$ on eelgrass performance were previously quantified using a population from the cool and thermally stable eastern Pacific waters of central California, in which the ambient temperature ranged between 12 and $16^{\circ} \mathrm{C}$ across seasons (Palacios \& Zimmerman 2007).
Eelgrass from the Chesapeake region of the western Atlantic, however, are typically exposed to temperatures that range from wintertime lows near $5^{\circ} \mathrm{C}$ to summertime highs exceeding $25^{\circ} \mathrm{C}$. Temperatures can approach $30^{\circ} \mathrm{C}$ during particularly warm summers, stressing eelgrass meadows throughout the southern Chesapeake Bay (Orth \& Moore 1983, Moore \& Jarvis 2008, Moore et al. 2012). Eelgrass can acclimate to temperatures below $25^{\circ} \mathrm{C}$ (Zimmerman et al. 1989), but exposure to simulated heat waves above $25^{\circ} \mathrm{C}$ causes die-backs (Ehlers et al. 2008) that can be linked to impaired photosynthetic performance (Winters et al. 2011) as well as to the differential effects on respiration and $\mathrm{CO}_{2}$-limited photosynthesis that make eelgrass vulnerable to negative carbon balance above $25^{\circ} \mathrm{C}$ (Evans et al. 1986, Zimmerman et al. 1989). $\mathrm{CO}_{2}$ stimulation of photosynthesis should reduce eelgrass vulnerability to negative carbon balance that is likely to occur with increasing frequency as the climate warms (Zimmerman et al. 1997, 2015, Invers et al. 2001).

The goal of this experiment was to quantify the extent to which $\mathrm{CO}_{2}$ enrichment can improve the ability of eelgrass to tolerate stressful summer temperatures typical of the Chesapeake/Pamlico region that defines the southern limit of eelgrass distribution in the temperate western North Atlantic and to explore the longer-term impacts on plant size, biomass allocation between shoots and roots/rhizomes, flowering, leaf sugar, and photosynthetic pigment content. This experiment also tested model predictions based on short-term physiological experiments that prolonged $\mathrm{CO}_{2}$ enrichment could reduce the lethal impacts of high summertime water temperature on eelgrass survival (Zimmerman et al. 2015). The insights into processes controlling carbon balance in seagrasses provided by this experiment offer to improve our predictive understanding of the simultaneous impacts of ocean warming and carbonation/acidification on the photosynthetic metabolism, vegetative growth and reproductive success of seagrasses in the context of a changing ocean climate.

\section{MATERIALS AND METHODS}

\section{Experimental facility}

We constructed an experimental facility at the Virginia Aquarium \& Marine Science Center, adjacent to Owls Creek, VA, consisting of 20 fiberglass aquaria $\left(3 \mathrm{~m}^{3}\right.$ volume each, Fig. 1). The long axis of each aquarium was oriented in a north-south direction to 


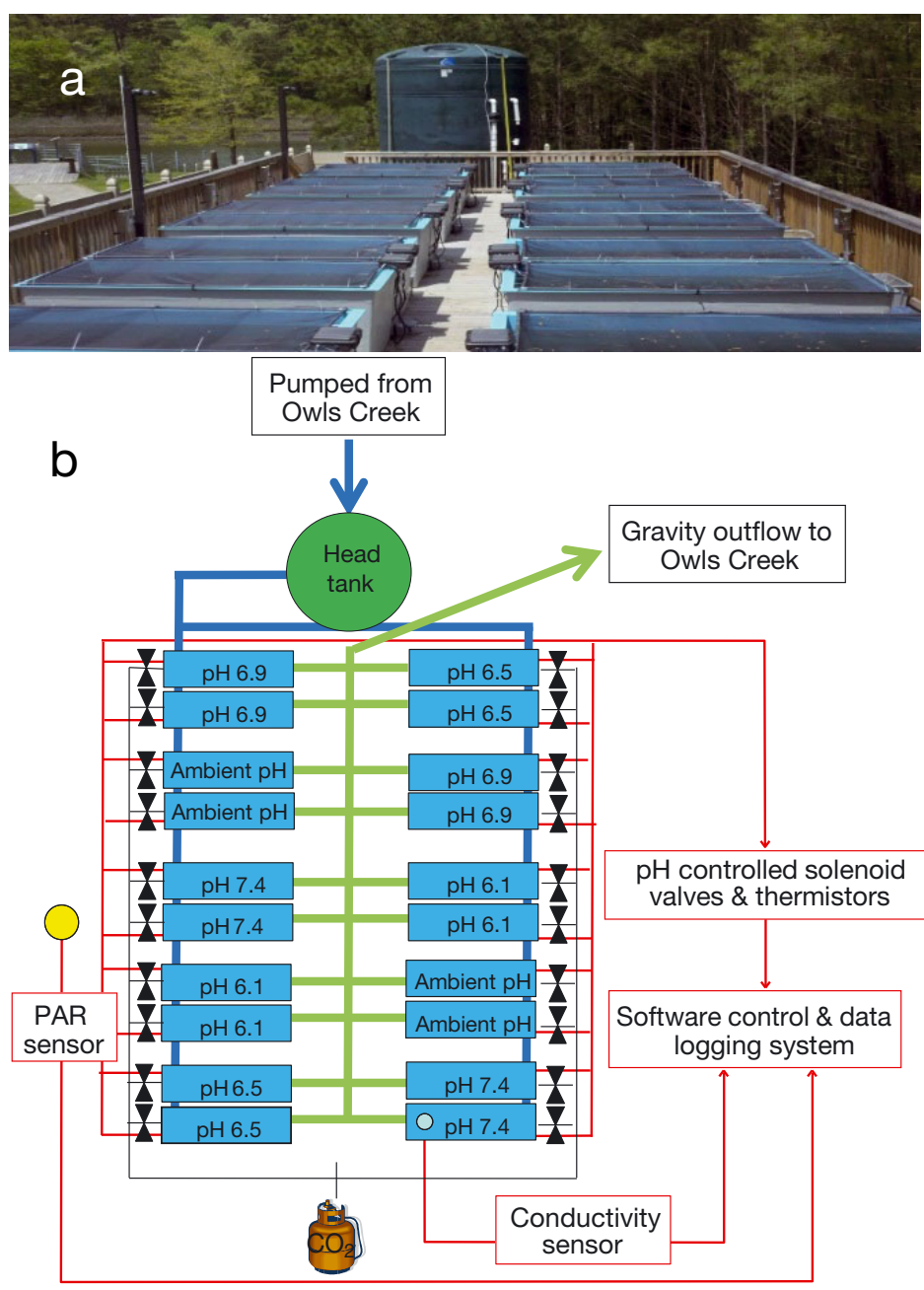

Fig. 1. (a) Experimental climate change facility at the Virginia Aquarium \& Marine Science Center showing the 20 fiberglass tanks $\left(3 \mathrm{~m}^{3}\right.$ each), $\mathrm{CO}_{2}$ control units mounted on each aquarium, and the large head tank. (b) Schematic diagram of the experimental system, illustrating the experimental aquaria (blue rectangles), water inflow (blue lines) and outflow (green lines), $\mathrm{CO}_{2}$ supply delivery system (tank black lines) with pH-controlled valves (black hourglass symbols), and environmental monitoring system (red lines and rectangles)

minimize the effect of wall shadows on irradiance to the plants. Natural water from Owls Creek was pumped directly into a large holding tank and then flowed by gravity through a bottom diffuser at the inlet of each aquarium. Flow rates were individually adjusted to ensure 10 complete turnovers in each aquarium per day (min. flow $=201 \mathrm{~min}^{-1}$ ). Water was discharged through a standpipe at the opposite end that maintained unidirectional (but not laminar) flow and a fixed water depth of $1 \mathrm{~m}$ in each aquarium. Water temperature was monitored by a high-precision thermistor (Omega 44005) placed in each aquarium. Thermistors were calibrated every 6 mo at 6 tempera- tures from 5 to $30^{\circ} \mathrm{C}$ using a temperaturecontrolled water bath (Fisher Scientific Isotemp). Salinity in each aquarium was measured a few times in May and June of 2013 using a hand-held refractometer (data not shown). No aquarium-to-aquarium differences were found among the refractometer measurements. Beginning in July 2013, salinity was continuously monitored within the system using a factorycalibrated SeaBird SBE37-SM CTD installed into one of the aquaria; all values are reported using the Practical Salinity Scale (PSS, Lewis 1980). Incident downwelling plane irradiance (photosynthetically active radiation, in air) was monitored with a factory-calibrated LiCor Li190 quantum radiometer. A layer of neutraldensity window screening (60\% transmission) prevented photodamage to upper leaf surfaces in the very shallow water of the aquaria. All instrument data were recorded at 10 min intervals using a National Instruments (NI) data logging and control system and custom software written in LabVIEW®. The aquaria and eelgrass shoots were cleaned weekly to remove biofilms and leaf epiphytes as well as any animals (fish, crabs, littleneck clams) introduced with the water. Mixing within the aquaria was accomplished by forcing air from a high-performance aquarium compressor through a $2 \mathrm{~m}$ length of Pentair Bio-Weave® diffuser hose running along the bottom of each aquarium.

Beverage-grade $\mathrm{CO}_{2}$ was injected into the air stream at each aquarium (except ambient) beginning 1 June 2013 and continued through November 302014 (18 mo) using solenoid valves individually controlled by Eutech Alpha pH 190 controller/transmitters equipped with submersible glass electrodes. Controllers were poised at 5 different $\mathrm{pH}$ values (4 aquaria at each $\mathrm{pH}$ ) ranging from ambient $(\mathrm{pH} \sim 7.7$, no $\mathrm{CO}_{2}$ addition) to $\mathrm{pH} 6.0\left(\left[\mathrm{CO}_{2(\mathrm{aq})}\right]=2121 \mu \mathrm{M}\right)$ at intervals of approximately $0.5 \mathrm{pH}$ unit as indicated on Fig. 1. The $5 \mathrm{pH}$ treatments were distributed evenly between the 2 rows of 10 aquaria ( 2 replicate $\mathrm{pH}$ treatments per row). The position of the $\mathrm{pH}$ treatments in each row was determined randomly except that replicate $\mathrm{pH}$ treatments were located adjacent to each other in the 2 rows because our initial plan was to heat 1 aquarium of each $\mathrm{pH}$ pair $5^{\circ} \mathrm{C}$ above ambient to achieve stressful temperature conditions during the summer. However, the ambient summertime temperature reached $30^{\circ} \mathrm{C}$ in both years, and we elected not to heat the aquaria as temperatures 
above $30^{\circ} \mathrm{C}$ are likely to produce acute thermal stress (Zimmerman et al. 1989) that was beyond the scope of this experiment. Since all aquaria were fed from the same water source and our monitoring data revealed no position effects in terms of light, temperature or salinity among the aquaria, we elected not to randomly redistribute the $\mathrm{pH}$ pairs in each row after the experiment had begun. Potential effects of aquarium position were subsequently ignored, and each aquarium was treated as an independent replicate in the statistical analysis of the experimental data.

The $\mathrm{pH}$ electrodes were cleaned and the $\mathrm{pH}$ controller systems calibrated weekly against NIST SRM $185 \& 186$ standard buffers ( $\mathrm{pH} 4,7$ and 10). Although $\left[\mathrm{CO}_{2(\mathrm{aq})}\right]$ at $\mathrm{pH}$ settings below 7.5 exceeded the range of ocean acidification predicted by the IPCC through the end of this century, estuarine systems are known to experience a much wider and more temporally variable range in $\mathrm{pH} / \mathrm{CO}_{2}$ than the open ocean (Duarte et al. 2013, Waldbusser \& Salisbury 2014, Ruesink et al. 2015). More importantly, this range provided a useful gradient in $\mathrm{CO}_{2}$ availability required to determine functional responses (slopes and intercepts) necessary for predicting the performance of eelgrass in any $\mathrm{CO}_{2}$ world - past, present or future.

Alkalinity was determined approximately weekly by automated titration using $0.020 \mathrm{~N} \mathrm{HCl}$ (Gieskes \& Rodgers 1973) and showed a strong predictive relationship with salinity: alkalinity $\left(\mu \mathrm{mol} \mathrm{\textrm {kg } ^ { - 1 }}\right.$ seawater $[\mathrm{SW}])=(49.61 \times$ salinity $\left.)+694.79, \mathrm{r}^{2}=0.86\right)$. Because no other acidifying agents or buffers were employed, alkalinity values derived from the salinity record, along with temperature and $\mathrm{pH}$, were used to determine the total $\mathrm{CO}_{2}\left(\Sigma \mathrm{CO}_{2}\right)$ content in each experimental aquarium as well as the distribution of $\mathrm{\Sigma CO}_{2}$ into the constituent fractions of $\mathrm{CO}_{2(\mathrm{aq})}, \mathrm{HCO}_{3}{ }^{-}$and $\mathrm{CO}_{3}{ }^{-}$ using CO2SYS (Ver. 01.05, Lewis \& Wallace 1998).

\section{Eelgrass source population and transplants}

Vegetative shoots were collected by SCUBA divers from a recently restored eelgrass meadow in South Bay, a coastal lagoon at the southern end of the Delmarva Peninsula (Orth et al. 2010), and transported to the experimental facility in insulated coolers in May 2013. Approximately 50 individual vegetative shoots with intact rhizomes and root bundles were transplanted into rectangular fiberglass-reinforced plastic containers $\left(0.04 \mathrm{~m}^{3}\right.$ volume, $0.075 \mathrm{~m}^{2}$ surface area) filled with clean intertidal sediment (sand) collected from the Old Dominion University (ODU) sailing center on the Elizabeth River, Norfolk, VA, resulting in an initial density of 700 shoots $\mathrm{m}^{-2}$. Five containers were placed into each aquarium at a water depth of $0.85 \mathrm{~m}$, placing the top of the canopy at about $0.5 \mathrm{~m}$ beneath the surface of the water at the beginning of the experiment.

\section{Whole plant performance}

All shoots were counted in every container and their flowering status noted each month from May 2013 to October 2014 (18 mo total). All abscised leaves and floating dead shoots were removed from the aquaria every few days. One shoot from each container was randomly selected each month and marked with a 20 gauge hypodermic needle $1 \mathrm{wk}$ prior to measurement using the hole-punch method (Zieman 1974, Zimmerman et al. 1996). Marked plants were also tagged with a small plastic cable tie to prevent resampling the same shoots in consecutive months. Young unmarked leaves were assumed to be new growth. The length of new leaf material below the punch mark and the total length of all leaves were measured to the nearest millimeter using a flexible meter tape. Leaf width (nearest $0.1 \mathrm{~mm}$ ) was measured with a digital caliper. Total leaf area $\left(\mathrm{cm}^{2}\right.$ shoot $^{-1}$ ) was calculated by summing the 1 -sided area (leaf length $\times$ leaf width) of all leaves of the shoot. Absolute growth $\left(\mathrm{cm}^{2}\right.$ shoot $\left.{ }^{-1} \mathrm{~d}^{-1}\right)$ was calculated by normalizing the new leaf area by the elapsed time (d) since the shoot was marked. Specific growth $\left(\% \mathrm{~d}^{-1}\right)$ was calculated by normalizing absolute growth rates by the total leaf area measured at the end of the marking period.

Biomass allocation among shoots, rhizomes, and roots was measured only at the end of the experiment in October 2014 because it required destructive sampling of the shoots. Three shoots were carefully removed from the sediment in each aquarium by hand, to avoid breaking rhizomes and roots, and returned to the laboratory for determination of fresh weight, dry weight, and chemical analysis of leaves, rhizomes, and roots. The average results from each aquarium, without error estimates for within-tank replication, were used in subsequent statistical analyses.

\section{Chemical composition}

Each month, a segment of leaf No. 2 (No. 1 was the youngest leaf) was collected from each shoot that was marked for growth. Leaf epiphytes were removed by gentle scraping with a razor blade. Fresh 
leaf segments were ground in ice-cold $80 \%$ acetone, and pigment content $(\mathrm{chl} a, \mathrm{chl} b$ and total carotenoids) was determined spectrophotometrically using the equations of Lichtenthaler \& Wellburn (1983) The remaining leaf samples were dried at $60^{\circ} \mathrm{C}$ for $48 \mathrm{~h}$ and ground in liquid nitrogen. Sucrose was extracted from the ground dry tissue 3 times using hot $\left(80^{\circ} \mathrm{C}\right)$ ethanol (Zimmerman et al. 1989). The 3 extractions were combined, and an aliquot was evaporated to dryness under a stream of compressed air, redissolved in distilled water, and analyzed spectrophotometrically using a resorcinol assay standardized to sucrose (Huber \& Israel 1982).

\section{Statistical analysis}

Within-aquarium replicate measures of each performance property were combined each month to generate statistically independent means for each aquarium (without error), resulting in 4 statistically independent replicate measurements for each $\mathrm{CO}_{2 \text { (aq) }}$ treatment each month. Although $\mathrm{CO}_{2(\mathrm{aq})}$ concentrations in the aquaria were manipulated using the $\mathrm{pH}$ controllers, they were also affected by salinity/alkalinity and especially water temperature such that $\left[\mathrm{CO}_{2(\mathrm{aq})}\right]$ was not absolutely fixed across time (see Fig. 2e). Consequently, statistical significance of treatment effects were determined using a repeated-measures ANCOVA implemented in the mixed model analysis of the generalized linear models component of IBM SPSS Statistics 22 using Month (i.e. time) as the fixed factor (within subjects) and $\mathrm{pH}$ as the covariate (between subjects). The aquaria were treated as repeated subjects. Statistical differences among $\mathrm{CO}_{2(\mathrm{aq})}$-dependent slopes across time were determined by post hoc analysis of the $95 \%$ confidence intervals derived from the mixed model analysis. ANCOVA results for significance and linearity of the individual regression slopes for each monthly measurement are available from the Biological and Chemical Oceanography Data Management Office data repository (www.bcodmo.org/project/2141). Effects of pH on plant size and biomass allocation among leaves, rhizomes, and roots at the end of the experiment were quantified using Model I linear regression. All error terms are expressed as standard errors unless otherwise noted.

\section{Heat maps}

Measures of whole plant performance and chemical composition are presented as colored contour plots across the experimental domain defined by $\mathrm{CO}_{2(\mathrm{aq})} / \mathrm{pH}$ (vertical axes) and time (horizontal axes) using the mean value for each treatment at each time point. The $5 \mathrm{CO}_{2(\mathrm{aq})} / \mathrm{pH}$ treatments are indicated by the tick marks on the left vertical axis of each heat map. Tick marks on the temporal (horizontal) axes indicate the middle of each month when performance measures were taken. Regression slopes and their standard errors relating whole plant performance and chemical composition to $\log \left[\mathrm{CO}_{2(\mathrm{aq})}\right]$ were computed using all the aquarium replicates (4 per $\mathrm{CO}_{2(\text { aq) }} / \mathrm{pH}$ treatment) in a Model I regression. White fields on the heat maps indicate missing data values.

\section{RESULTS}

\section{Experimental conditions}

The outdoor aquarium system used for this experiment exposed all treatments to daily and seasonal variations in total solar radiation, ambient temperature and salinity. Irradiance varied seasonally in response to solar elevation and day length, producing 3-fold more total daily irradiance in summer than winter (Fig. 2a). Day-to-day variations in irradiance resulting from weather and clouds often exceeded the seasonal range in total daily irradiance, particularly in summer. The seasonal cycle in water temperature lagged the pattern in total daily irradiance by 6 to 8 wk (Fig. 2b). Temperature varied among the aquaria by $<1^{\circ} \mathrm{C}$ and cycled daily by $\sim 5^{\circ} \mathrm{C}$ around the mean values in summer and $2^{\circ} \mathrm{C}$ in winter. Summer high temperatures reached $30^{\circ} \mathrm{C}$ each summer and exceeded the $25^{\circ} \mathrm{C}$ threshold for eelgrass stress (Evans et al. 1986, Zimmerman et al. 1989) for at least $1 \mathrm{~h} \mathrm{~d}^{-1}$ on 97 and $124 \mathrm{~d}$ in 2013 and 2014, respectively. Water temperature exceeded the $25^{\circ} \mathrm{C}$ threshold all day long for 48 and 73 d in 2013 and 2014, respectively. Winter low temperatures averaged about $5^{\circ} \mathrm{C}$ from January through March 2014 and approached $0^{\circ} \mathrm{C}$ on a few days in February 2014.

Hydrography of the Owls Creek source water is dominated by tidal exchange with the mid-Atlantic Ocean at Rudee Inlet, just south of the Chesapeake Bay mouth (Sisson et al. 2010), resulting in a mean salinity of $24 \pm 3$ (PSS) punctuated by brief spikes of low salinity resulting from local rainfall events and runoff into the watershed (Fig. 2c). Unlike irradiance and temperature, there was no obvious seasonal pattern in the salinity signal. Aragonite saturation of the source water, calculated from measured 

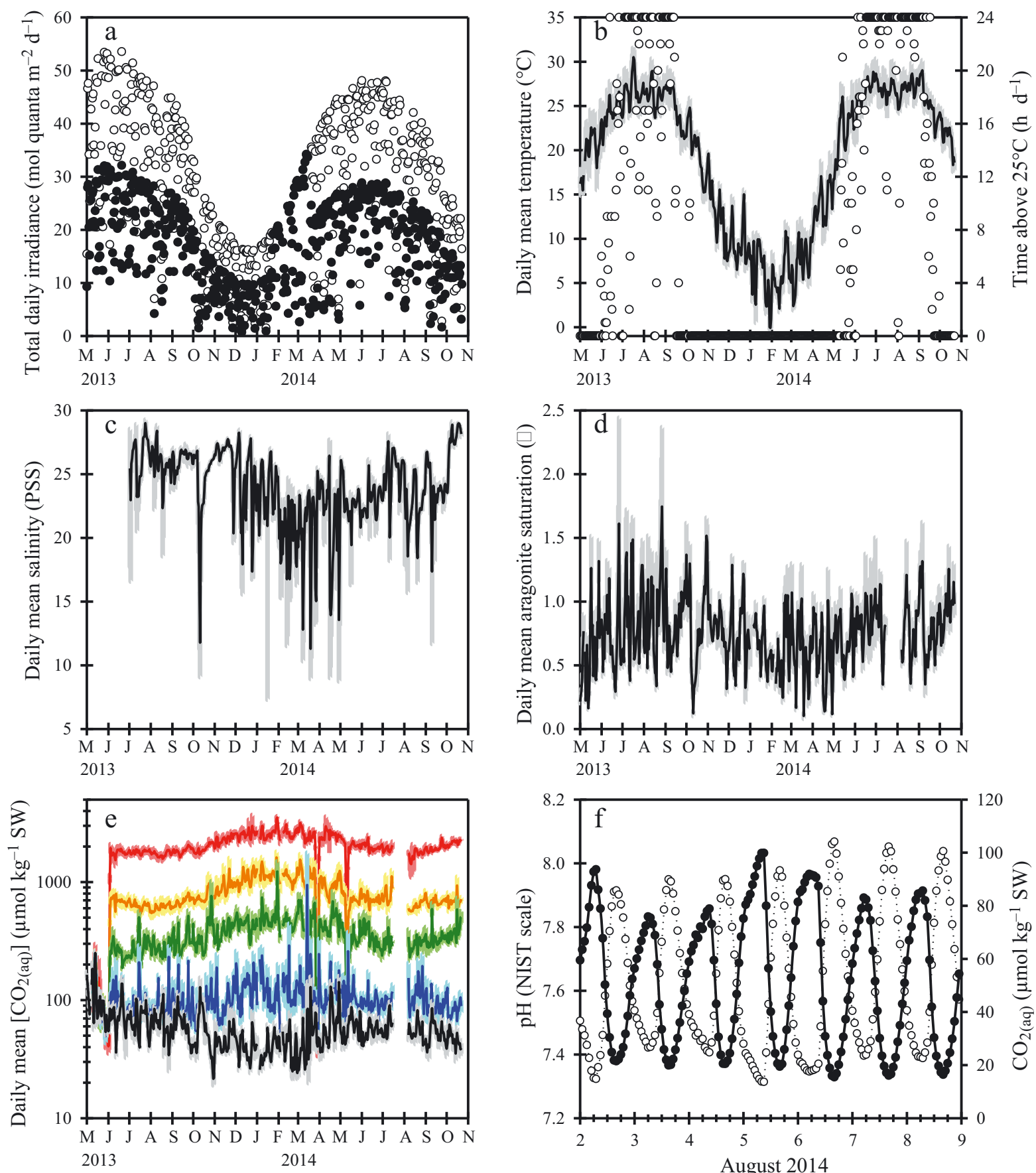

Fig. 2. Environmental conditions during the experiment. (a) Total daily irradiance. Open symbols represent unscreened values measured by the PAR sensor. Filled symbols represent the irradiance incident on the plants below the $40 \%$ reduction window screening. (b) Ambient temperature scaled according to the left vertical axis. Solid black line indicates the mean for all aquaria. Gray shading around the mean line indicates daily maximum and minimum values. Open symbols indicate the number of hours each day that temperature exceeded the $25^{\circ} \mathrm{C}$ threshold for temperature stress (right vertical axis). (c) Daily mean salinity starting in July 2013. Solid black line indicates the mean for all aquaria. Gray shading around the mean line indicates daily maximum and minimum values. (d) Daily mean aragonite saturation calculated from salinity, alkalinity, $\mathrm{pH}$, and temperature using CO2SYS. Solid black line indicates the mean for all aquaria. Gray shading around the mean line indicates daily maximum and minimum values. (e) Daily mean $\mathrm{CO}_{2(\mathrm{aq})}$ calculated for each $\mathrm{pH}$ treatment from salinity, alkalinity, $\mathrm{pH}$ and temperature using CO2SYS. Solid lines indicate the means for each treatment. Pastel shading around each line indicates daily maximum and minimum values. Red line: $\mathrm{pH} 6.1$, orange: $\mathrm{pH} 6.5$, green: $\mathrm{pH} 6.9$, blue: $\mathrm{pH} 7.4$, black: $\mathrm{pH} 7.7$ (ambient). (f) Hourly values of $\mathrm{pH}$ (open symbols) and $\mathrm{CO}_{2(\mathrm{aq})}$ (filled symbols) of the ambient treatment (no $\mathrm{CO}_{2}$ addition) from 2 to 8 August 2014. Major ticks on the time axis indicate local midnight (Eastern Standard Time). PSS: Practical Salinity Scale; SW: seawater 
values of salinity, alkalinity and $\mathrm{pH}$, was consistently $<1$ (median $\Omega=0.7$ ) but showed a high degree of daily and seasonal variability (min. $\Omega=0.04$, max. $\Omega=4.2$ ). Aragonite saturation was higher during the day $(\bar{\Omega}=0.96 \pm 0.01)$ than at night $(\bar{\Omega}=$ $0.60 \pm 0.01$ ), and more variable in summer $(\Omega$ daily range $=0.21$ to 2.48 ) than in winter $(\Omega$ daily range $=$ 0.15 to 1.40 , Fig. $2 d$ ).

Ambient $\mathrm{CO}_{2(\mathrm{aq})}$ concentrations in source water averaged $55 \pm 19 \mu \mathrm{mol} \mathrm{kg}^{-1} \mathrm{SW}$, depending on season and time of day (Fig. 2e, black line). Prior to the onset of $\mathrm{CO}_{2}$ enrichment on 1 June 2013, all aquaria experienced nearly identical variations in $\left[\mathrm{CO}_{2(\text { aq) }}\right]$ as well as temperature, salinity, alkalinity and $\mathrm{pH}$. The source-water $\mathrm{pH}$ was more variable and $\sim 0.5$ units lower during summer than winter, resulting in pre-dawn $\left[\mathrm{CO}_{2(\text { aq) }}\right]$ as much as 10 times above air saturation $\left(\sim 15 \mu \mathrm{mol} \mathrm{kg}{ }^{-1} \mathrm{SW}\right)$. $\left[\mathrm{CO}_{2(\mathrm{aq})}\right]$ approached (Fig. 2f) and occasionally dropped below (data not shown) air saturation during the daytime, thereby increasing the effect of $\mathrm{CO}_{2}$ limitation on photosynthesis of the plants in the unmanipulated aquaria. Despite natural fluctuations in ambient salinity, $\mathrm{pH}$ and $\mathrm{CO}_{2(\mathrm{aq})}$ of the source water, the experimental $\mathrm{CO}_{2}$ manipulation produced consistent $\left[\mathrm{CO}_{2(\mathrm{aq})}\right]$ and $\mathrm{pH}$ values across the treatments throughout the duration of the experiment (Fig. 2e, compare colored lines). The $3 \mathrm{wk}$ gap in $\left[\mathrm{CO}_{2(\mathrm{aq})}\right]$ and aragonite saturation data during July and August 2014 resulted from a lightning strike that temporarily disabled the NI data logger. Although $\mathrm{pH}$ data were not recorded during this period, the $\mathrm{pH}$ controllers for all aquaria operated normally. The irradiance and CTD sensors were equipped with backup data loggers that prevented loss of those data during this period. Because temperature across the aquaria varied by $<0.2^{\circ} \mathrm{C}$, temperature data from the CTD was used to fill the July to August 2014 gap in recorded aquarium temperature.

Concentrations of macronutrients in Owls Creek were monitored weekly by the Virginia Aquarium staff as part of their water quality monitoring program. Although there is considerable variability in ambient macronutrient concentrations in the creek waters, the mean concentration of dissolved inorganic nitrogen $\left(\mathrm{NO}_{3}{ }^{-}+\mathrm{NO}_{2}^{-}+\mathrm{NH}_{4}{ }^{+}\right)$was $11.3 \pm$ $0.6 \mu \mathrm{M}$ and orthophosphate was $1.4 \pm 0.1 \mu \mathrm{M}$ (W. M. Swingle unpubl. data), well above the levels required to saturate eelgrass growth (Zimmerman et al. 1987) but not high enough to cause eelgrass decline (Burkholder et al. 1992, Brun et al. 2002, van der Heide et al. 2008).

\section{Plant performance features}

Shoot numbers per container, a measure of plant survival, remained stable across all treatments for 2 mo after the initial transplanting in May 2013, indicating no significant effects of aquarium location or systemwide transplant shock (Fig. 3a, heat map). Although the $\mathrm{CO}_{2(\mathrm{aq})}$ treatments were initiated on 1 June 2013, the slopes of shoot number vs. $\log \left[\mathrm{CO}_{2(\mathrm{aq})}\right]$ were not significantly different from 0 in June and July, indicating no detectable effect on shoot numbers during the first 2 mo of $\mathrm{CO}_{2(\mathrm{aq})}$ enrichment (white symbols, Fig. 3a, Table 1). In August 2013, however, shoot numbers increased with $\left[\mathrm{CO}_{2(\mathrm{aq})}\right]$, as indicated by the statistically significant positive slopes (repeated-measures ANCOVA $\mathrm{p} \ll 0.05$, Table 1). By the end of summer 2013, shoot numbers of the $823 \mu \mathrm{M} \mathrm{CO}_{2 \text { (aq) }}(\mathrm{pH}$ 6.5) treatment nearly doubled through vegetative propagation, while less than half of the originally transplanted shoots survived in the ambient $\mathrm{CO}_{2(\mathrm{aq})}$ treatment. Shoot losses in the ambient $\mathrm{CO}_{2(\mathrm{aq})}$ treatment began in July 2013 as water temperature peaked and continued throughout the winter of 2013 to 2014 . In contrast, shoot numbers increased slowly via vegetative propagation through the fall and winter of 2013 in the 3 highest $\mathrm{CO}_{2(\mathrm{aq})}$ treatments and then increased dramatically at the beginning of 2014 (winter). This dramatic increase in vegetative propagation coincided with the increase in daily solar irradiance following the winter solstice (Figs. 2a \& 3a). The slope of shoot number vs. $\log \left[\mathrm{CO}_{2(\text { aq) }}\right]$ was highest from January to May of 2014 (Fig. 3a, white symbols and lines). Senescence of the flowering shoots after seed ripening in June and July 2014 (Fig. 3b) caused a transient loss of shoot numbers, most evident at high $\left[\mathrm{CO}_{2(\mathrm{aq})}\right]$ because of the high flowering rate, that subsequently recovered due to a new round of vegetative shoot propagation in the late summer and fall of 2014 (Fig. 3a). In contrast, vegetative shoot losses continued in the ambient $\mathrm{CO}_{2(\mathrm{aq})}$ treatment throughout the summer and fall of 2014. Differentiation of vegetative shoots into flowering shoots began as early as January 2014 in the other $\mathrm{CO}_{2(\mathrm{aq})}$ treatments and showed a strong, positive response to $\left[\mathrm{CO}_{2(\mathrm{aq})}\right]$ throughout the flowering period that ended in June 2014, reaching $50 \%$ of the shoot population grown under the 2 highest $\mathrm{CO}_{2(\mathrm{aq})}$ treatments during April and May 2014 (Fig. $3 \mathrm{~b}$, Table 1 ). In contrast, $<10 \%$ of the surviving shoots flowered in the ambient $\mathrm{CO}_{2(\mathrm{aq})}$ treatment, and the first flowering shoots did not appear until May 2014. Vegetative shoot size $\left(\mathrm{cm}^{2}\right.$ total leaf area) increased with $\left[\mathrm{CO}_{2(\mathrm{aq})}\right]$ throughout the summer and 

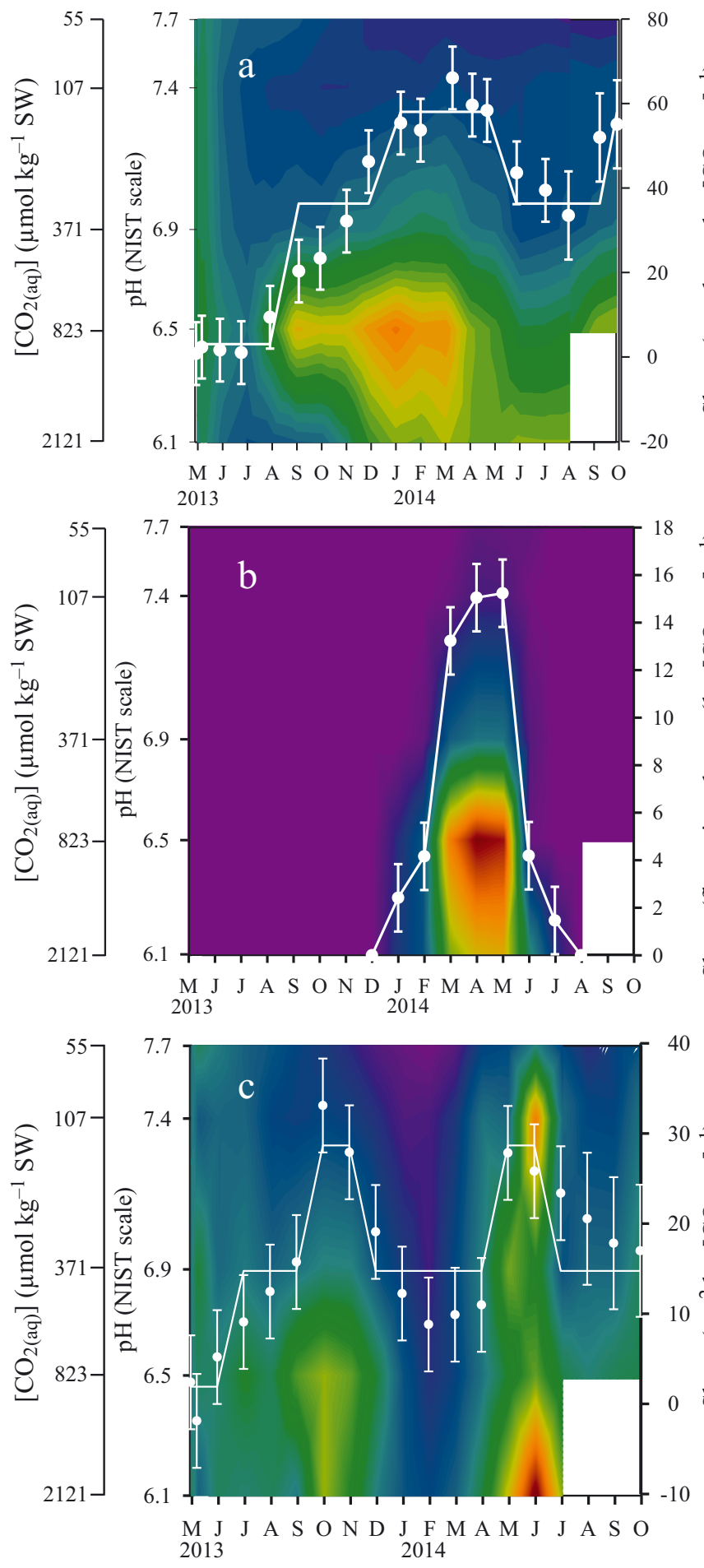

early fall 2013 period of warm water temperature $\left(>20^{\circ} \mathrm{C}\right)$, decreased through the cold winter of 2014 and increased with the return of warm water in the summer of 2014 (Fig. 3c, Table 1).

Absolute growth rates responded positively within 6 wk of initiating the $\mathrm{CO}_{2}$ treatment in June 2013, before differences in shoot survival or shoot size
Fig. 3. Heat maps. (a) Absolute shoot numbers contoured as a function of $\mathrm{pH}\left(\mathrm{CO}_{2(\mathrm{aq})}\right)$ treatment and time. (b) Flowering shoot numbers (percent of total shoots) contoured as a function of $\mathrm{pH} / \mathrm{CO}_{2(\mathrm{aq})}$ treatment and time. Slopes (white symbols) were calculated based on absolute numbers, not percentages. (c) Aboveground shoot size, expressed as $\mathrm{cm}^{2}$ of 1-sided leaf area per shoot. Tick marks on the left vertical axis of each plot indicate the mean $\mathrm{pH} / \mathrm{CO}_{2(\mathrm{aq})}$ value for each treatment. White symbols on each plot represent the slope of the response variable vs. $\log \left[\mathrm{CO}_{2(\mathrm{aq})}\right]$ derived from linear regression analysis. Error bars represent $\pm 1 \mathrm{SE}$ of the regression slopes. Horizontal lines connect slopes that were determined to be statistically identical by ANCOVA and post hoc analysis. The white fields in the lower right corner of each plot indicate no data for the $2121 \mu \mathrm{M} \mathrm{CO}_{2(\mathrm{aq})}$ / pH 6.1 treatment. SW: seawater

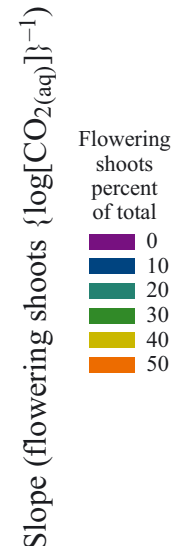

were statistically significant (Fig. 4a, Table 1). Absolute growth rates continued to respond in a positive, logarithmic fashion to the $\left[\mathrm{CO}_{2(\mathrm{aq})}\right]$ gradient throughout the summer and early fall, during which time water temperature consistently exceeded the previously established $25^{\circ} \mathrm{C}$ threshold for stress. Absolute growth rates declined in all treatments, and the $\mathrm{CO}_{2 \text { (aq) }}$ effect (slope) decreased to near 0 during the winter period of low light availability and cold temperature. The $\mathrm{CO}_{2(\mathrm{aq})}$ effect, however, resumed as temperature increased during spring 2014 and continued throughout the warm summer of 2014. When normalized for plant size, the effect of $\left[\mathrm{CO}_{2(\mathrm{aq})}\right]$ on relative growth rate disappeared (slopes $=0$ ), but the seasonal pattern of high summer growth and low winter growth remained strong (Fig. 4b, Table 1). Statistically significant dips in relative shoot growth (but not absolute growth) observed between March and June 2014 coincided with the maturation of flowering shoots that may place higher demand on carbon resources than vegetative shoots.

At the end of the 18 mo experiment, plants exposed to the highest $\mathrm{CO}_{2(\mathrm{aq})}$ treatments were about 3 times larger than the plants grown at ambient $\left[\mathrm{CO}_{2(\mathrm{aq})}\right]$ (Fig. 5a, Table 2). Further, the fraction of biomass allocated to aboveground leaves increased across the $\left[\mathrm{CO}_{2(\mathrm{aq})}\right]$ gradient such that the ratio of Shoot/(Root + Rhizome) was $50 \%$ higher in plants grown at the 
Table 1. Summary ANCOVA tables for Type III tests of fixed effects (Month and $\mathrm{pH}$ ) using the mixed linear model routine implemented in SPSS. FW: fresh weight

\begin{tabular}{|c|c|c|c|c|c|}
\hline Dependent variable & Source & Effects df & Error df & $F$ & $\mathrm{p}$ \\
\hline $\begin{array}{l}\text { Total shoot count } \\
\left(\text { shoots tray }^{-1}\right)\end{array}$ & $\begin{array}{l}\text { Month } \\
\mathrm{pH} \\
\text { Month } \times \mathrm{pH}\end{array}$ & $\begin{array}{c}18 \\
1 \\
18\end{array}$ & $\begin{array}{c}258 \\
31 \\
258\end{array}$ & $\begin{array}{r}5.84 \\
62.19 \\
5.12\end{array}$ & $\begin{array}{l}<0.001 \\
<0.001 \\
<0.001\end{array}$ \\
\hline $\begin{array}{l}\text { Flowering shoot } \\
\text { count ( } \% \text { of total) }\end{array}$ & $\begin{array}{l}\text { Month } \\
\mathrm{pH} \\
\text { Month } \times \mathrm{pH}\end{array}$ & $\begin{array}{c}18 \\
1 \\
18\end{array}$ & $\begin{array}{c}228 \\
48 \\
227\end{array}$ & $\begin{array}{l}13.37 \\
21.29 \\
10.85\end{array}$ & $\begin{array}{l}<0.001 \\
<0.001 \\
<0.001\end{array}$ \\
\hline Shoot size $\left(\mathrm{cm}^{2}\right)$ & $\begin{array}{l}\text { Month } \\
\mathrm{pH} \\
\text { Month } \times \mathrm{pH}\end{array}$ & $\begin{array}{c}18 \\
1 \\
18\end{array}$ & $\begin{array}{c}200 \\
90 \\
210\end{array}$ & $\begin{array}{r}2.97 \\
97.39 \\
2.52\end{array}$ & $\begin{array}{r}<0.001 \\
<0.001 \\
0.001\end{array}$ \\
\hline $\begin{array}{l}\text { Absolute growth } \\
\text { rate }\left(\mathrm{cm}^{2} \mathrm{~d}^{-1}\right)\end{array}$ & $\begin{array}{l}\text { Month } \\
\mathrm{pH} \\
\text { Month } \times \mathrm{pH}\end{array}$ & $\begin{array}{c}18 \\
1 \\
18\end{array}$ & $\begin{array}{c}203 \\
80 \\
201\end{array}$ & $\begin{array}{r}5.93 \\
72.22 \\
4.74\end{array}$ & $\begin{array}{l}<0.001 \\
<0.001 \\
<0.001\end{array}$ \\
\hline $\begin{array}{l}\text { Specific growth } \\
\text { rate }\left(\mathrm{d}^{-1}\right)\end{array}$ & $\begin{array}{l}\text { Month } \\
\mathrm{pH} \\
\text { Month } \times \mathrm{pH}\end{array}$ & $\begin{array}{c}18 \\
1 \\
18\end{array}$ & $\begin{array}{l}178 \\
104 \\
178\end{array}$ & $\begin{array}{l}1.63 \\
0.05 \\
1.18\end{array}$ & $\begin{array}{r}<0.001 \\
0.827 \\
0.278\end{array}$ \\
\hline $\begin{array}{l}\text { Sucrose } \\
\qquad\left(\mu \mathrm{mol} \mathrm{g}{ }^{-1} \mathrm{FW}\right)\end{array}$ & $\begin{array}{l}\text { Month } \\
\mathrm{pH} \\
\text { Month } \times \mathrm{pH}\end{array}$ & $\begin{array}{c}17 \\
1 \\
17\end{array}$ & $\begin{array}{c}291 \\
19 \\
291\end{array}$ & $\begin{array}{r}4.68 \\
261.87 \\
3.83\end{array}$ & $\begin{array}{l}<0.001 \\
<0.001 \\
<0.001\end{array}$ \\
\hline $\begin{array}{l}\Sigma \operatorname{chl}(a+b) \\
\left(\mathrm{mg} \mathrm{g}^{-1} \mathrm{FW}\right)\end{array}$ & $\begin{array}{l}\text { Month } \\
\mathrm{pH} \\
\text { Month } \times \mathrm{pH}\end{array}$ & $\begin{array}{c}14 \\
1 \\
14\end{array}$ & $\begin{array}{c}252 \\
18 \\
252\end{array}$ & $\begin{array}{r}2.98 \\
144.44 \\
2.50\end{array}$ & $\begin{array}{r}<0.001 \\
<0.001 \\
0.002\end{array}$ \\
\hline $\begin{array}{r}\Sigma \text { Carotenoids } \\
\left(\mathrm{mg} \mathrm{g}^{-1} \mathrm{FW}\right)\end{array}$ & $\begin{array}{l}\text { Month } \\
\mathrm{pH} \\
\text { Month } \times \mathrm{pH}\end{array}$ & $\begin{array}{c}13 \\
1 \\
13\end{array}$ & $\begin{array}{c}234 \\
18 \\
234\end{array}$ & $\begin{array}{r}1.58 \\
138.69 \\
1.61\end{array}$ & $\begin{array}{r}0.093 \\
<0.001 \\
0.083\end{array}$ \\
\hline
\end{tabular}

highest $\left[\mathrm{CO}_{2(\mathrm{aq})}\right]$ (Fig. 5b, Table 2). However, the distribution of biomass between roots and rhizomes remained constant across the $\left[\mathrm{CO}_{2(\mathrm{aq})}\right]$ gradient (Fig. 5c, Table 2). Visual examples of the differences in surviving shoot numbers, plant size and biomass allocation across treatments are illustrated in Fig. 6.

Leaf sugar content also responded positively to higher $\left[\mathrm{CO}_{2(\text { aq) }}\right]$ (Fig. 7a, Table 1). Differences across the $\mathrm{CO}_{2(\text { aq) }}$ gradient were most pronounced during the summer of 2013, when leaf sugar concentration in the highest $\mathrm{CO}_{2(\text { aq) }}$ treatment was 5-fold higher than the ambient treatment, and the slope across all treatments approached $200 \mu \mathrm{mol}$ sucrose $\left(\mathrm{g}^{-1}\right.$ fresh weight) (log[$\left.\left[\mathrm{CO}_{2(\mathrm{aq})}\right]^{-1}\right)$. Sugar concentrations peaked

Table 2. Regression statistics for the effect of $\mathrm{pH}$ on $\Sigma$ Plant biomass, Shoot/(Root + Rhizome) and Root/Rhizome at the end of the experiment in October 2014 shown in Fig. 5. FW: fresh weight

\begin{tabular}{|lcccccccc|}
\hline Dependent variable & Slope & SE & Intercept & SE & $\mathrm{r}^{2}$ & df & $F$ & $\mathrm{p}$ \\
\hline IPlant biomass (g FW) & -1.46 & 0.47 & 10.10 & 3.33 & 0.390 & 14 & 9.0 & 0.01 \\
Shoot/(Root + Rhizome) & -1.86 & 0.64 & 17.23 & 4.54 & 0.388 & 14 & 8.9 & 0.01 \\
Root/Rhizome & -0.12 & 1.05 & 3.19 & 7.48 & 0.001 & 14 & 0.016 & 0.90 \\
\hline
\end{tabular}

in all $\mathrm{CO}_{2(\mathrm{aq})}$ treatments during January and February 2014, when ambient temperature (Fig. 2b), rates of vegetative shoot proliferation (Fig. 3a) and leaf growth (Fig. 4a) were at a minimum, and flowering shoot differentiation was just beginning (Fig. 2b). Although the relationship between leaf sugar and $\mathrm{CO}_{2(\text { aq) }}$ remained positive throughout the duration of the experiment, the slope declined during the summer of 2014 as vegetative shoot proliferation increased following the senescence of flowering shoots (Fig. 3a).

As with all other performance measures, leaf total chlorophyll ( $\mathrm{chl} a+$ chl b) concentrations were identical across all treatments at the beginning of the experiment in May 2013 (Fig. 7b, Table 1). Unlike the other performance measures, however, total chlorophyll concentrations decreased in response to increasing $\left[\mathrm{CO}_{2(\mathrm{aq})}\right]$ (Fig. $7 \mathrm{~b}$, Table 1). Although total chlorophyll increased in all treatments during winter in a manner reminiscent of photoacclimation, the slope remained significantly negative throughout the course of the experiment (Table 1). Total carotenoid content also decreased in response to increasing $\left[\mathrm{CO}_{2(\mathrm{aq})}\right]$, and the slope remained significantly negative throughout the experimental period (Fig. 7c, Table 1).

\section{DISCUSSION}

This experiment demonstrated that $\mathrm{CO}_{2}$ stimulation of primary production can enhance the summertime survival, growth, and proliferation of perennial eelgrass from the Chesapeake region that is regularly impacted by summer heat stress (Moore \& Jarvis 2008, Jarvis et al. 2012, Moore et al. 2012). These results reinforce the emerging paradigm that eelgrass may benefit significantly from a high- $\mathrm{CO}_{2}$ world. Furthermore, the experiment demonstrated a logarithmic response to $\left[\mathrm{CO}_{2(\mathrm{aq})}\right]$ in terms of shoot proliferation, size, growth, and sugar accumulation that was fundamentally consistent with model predictions based on meta- 


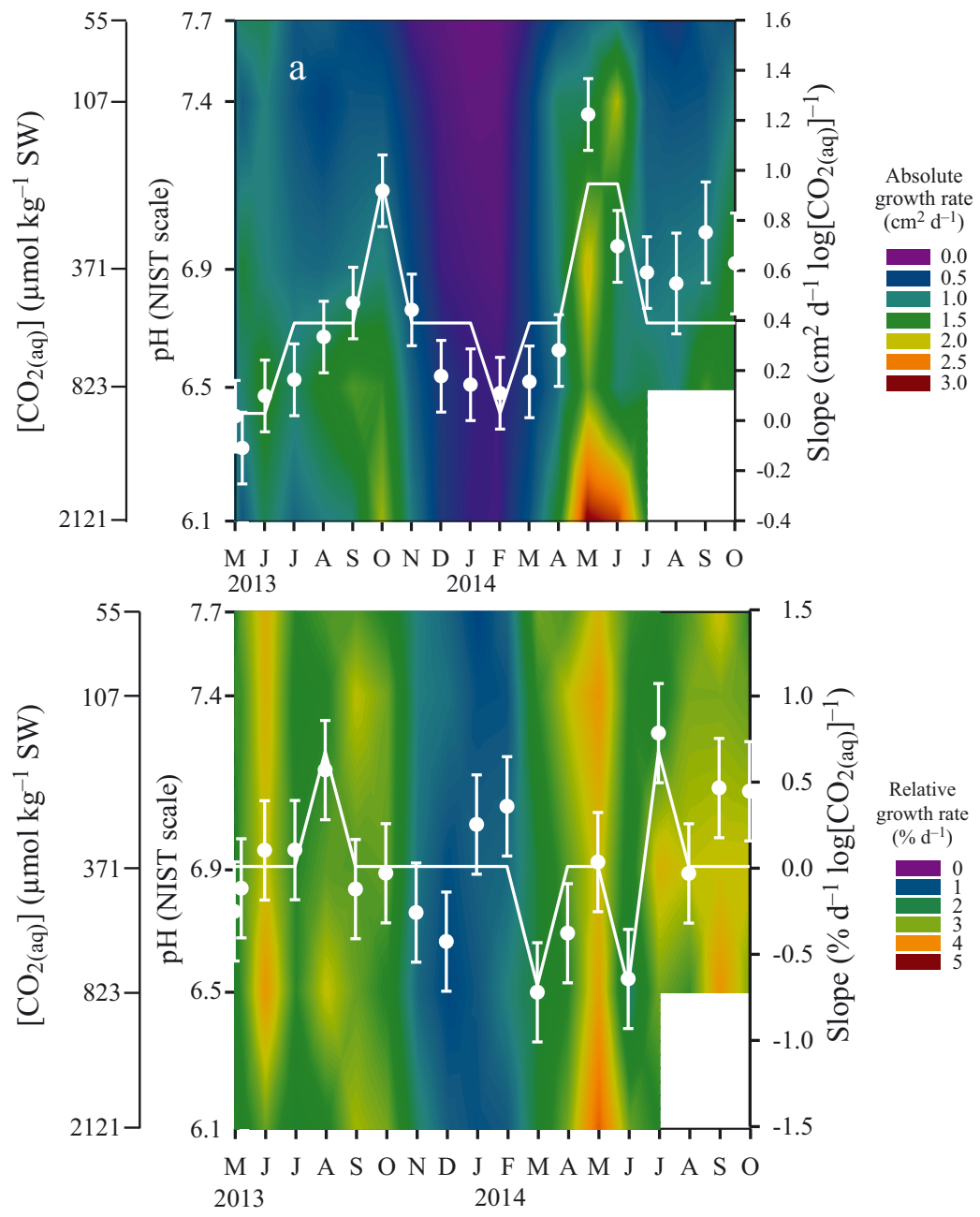

Fig. 4. Heat maps. (a) Absolute vegetative shoot growth rate contoured as a function of $\mathrm{pH} / \mathrm{CO}_{2(\mathrm{aq})}$ treatment and time. (b) Relative shoot growth contoured as a function of $\mathrm{pH} / \mathrm{CO}_{2(\mathrm{aq})}$ treatment and time. Tick marks on the left vertical axis of each plot indicate the mean $\mathrm{pH} / \mathrm{CO}_{2(\mathrm{aq})}$ value for each treatment. White symbols on each plot represent the slope of the response variable vs. $\log \left[\mathrm{CO}_{2(\mathrm{aq})}\right]$ derived from linear regression analysis. Error bars represent $\pm 1 \mathrm{SE}$ of the regression slope. Horizontal lines connect slopes that were determined to be statistically identical by ANCOVA and post hoc analysis. The white fields in the lower right corner of each plot indicate no data for the $2121 \mu \mathrm{M} \mathrm{CO}_{2(\mathrm{aq})} / \mathrm{pH} 6.1$ treatment. SW: seawater

Hall-Spencer et al. 2008, Jiang et al. 2010, Campbell \& Fourqurean 2013), differences in $\mathrm{CO}_{2}$ stimulation of photosynthesis among seagrass species (e.g. Invers et al. 2001) suggest that the degree of relief provided by increasing $\mathrm{CO}_{2}$ may differ among seagrass populations worldwide.

Not only did the $\mathrm{CO}_{2}$ subsidy lead to higher sucrose concentrations and prevent shoot losses during the warm summer when water temperature exceeded the $25^{\circ} \mathrm{C}$ threshold for thermal stress, it also promoted vegetative proliferation that resulted in a doubling of shoot numbers under the highest $\left[\mathrm{CO}_{2(\mathrm{aq})}\right]$ by the end of summer 2013. A similar doubling in shoot number was observed at high $\left[\mathrm{CO}_{2(\mathrm{aq})}\right]$ in a previous experiment with Pacific coast eelgrass that did not involve thermal stress but without the corresponding die-off at low $\left[\mathrm{CO}_{(2 \mathrm{aq})}\right]$ (Palacios \& Zimmerman 2007). That earlier study also showed no effect of $\left[\mathrm{CO}_{2(\mathrm{aq})}\right]$ on aboveground shoot size or growth rate but a significant linear increase in biomass allocated to rhizomes, in contrast to this experiment in which the increased fixed carbon was allocated to aboveground and belowground tissues in an allometric ratio that slightly favored aboveground biomass over roots and rhizomes. Further evidence of the nearly allometric response to $\mathrm{CO}_{2(\mathrm{aq})}$ enrichment by the Chesapeake eelgrass population was provided by the disappearance of a significant effect when growth rates were normalized to plant size.

Heat stress experiments performed on eelgrass populations from the Adriatic

bolic carbon balance (Zimmerman et al. 2015) derived from short-term laboratory experiments performed with other eelgrass populations from cool ocean climates (Zimmerman et al. 1995, 1997, Palacios \& Zimmerman 2007). Thus, rather than acting in a neutral fashion or as an independent stressor, it appears that ocean carbonation (ocean acidification) can serve as a quantitative antagonist to counter the negative impact of climate warming on eelgrass growth and survival. Although our results may apply to $\mathrm{CO}_{2}$-limited seagrasses in other tropical and temperate environments (Beer et al. 1977, Durako 1993, and Baltic Seas without a $\mathrm{CO}_{2}$ subsidy at a maximum temperature of $25^{\circ} \mathrm{C}$ revealed significant up-regulation of genes coding for a variety of stress proteins in addition to significant shoot losses (Bergmann et al. 2010, Winters et al. 2011). Although this experiment produced similar shoot losses in the absence of a $\mathrm{CO}_{2}$ subsidy, increasing $\mathrm{CO}_{2}$ availability eliminated the lethal effects of temperature on whole plant sugar accumulation, growth and vegetative proliferation. At present, it is unclear whether growth under elevated $\left[\mathrm{CO}_{2(\mathrm{aq})}\right]$ prevented thermal stress directly or provided the shoots with sufficient carbon reserves to support 


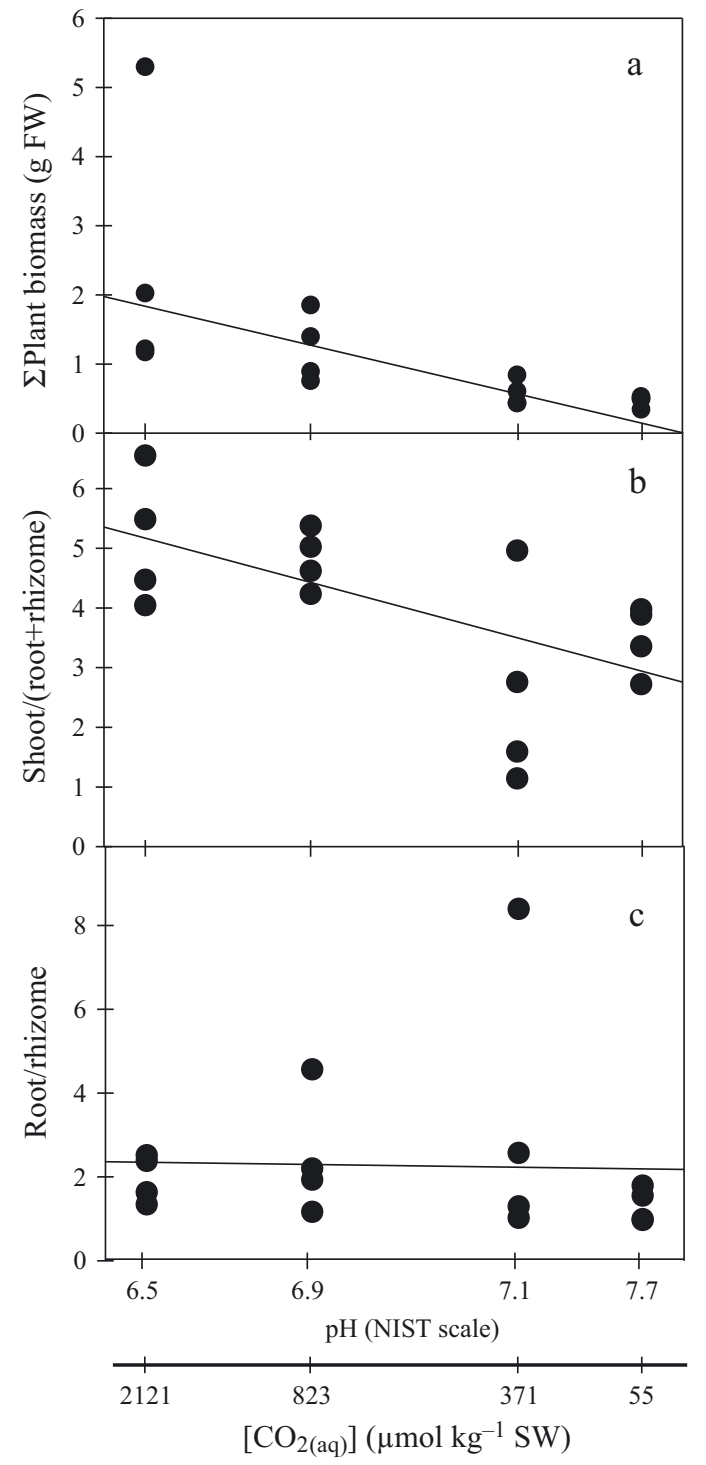

Fig. 5. (a) Total plant biomass (leaves + roots + rhizomes) at the end of the experiment in October 2014 plotted as a function of $\mathrm{pH} / \mathrm{CO}_{2(\mathrm{aq})}$ treatment revealed a significant linear relationship (Table 2). (b) Fraction of total biomass allocated to aboveground leaves at the end of the experiment in October 2014 plotted as a function of $\mathrm{CO}_{2}$ treatment revealed a significant linear relationship (Table 2). (c) Fraction of belowground biomass allocated between roots and shoots was not significantly affected by $\mathrm{CO}_{2}$ treatment (Table 2). FW: fresh weight; SW: seawater

metabolic repair without negatively impacting growth and other performance features. The increased plant size and shoot number, however, suggests that the $\mathrm{CO}_{2}$ effect was far greater than the simple suppression of stress, and for the eelgrass population examined here, the proximate effect of temperature was on metabolic carbon balance. There may be significant population-level differences in the ability of $\mathrm{CO}_{2}$ to rescue eelgrass from thermal stress, as significant ge-

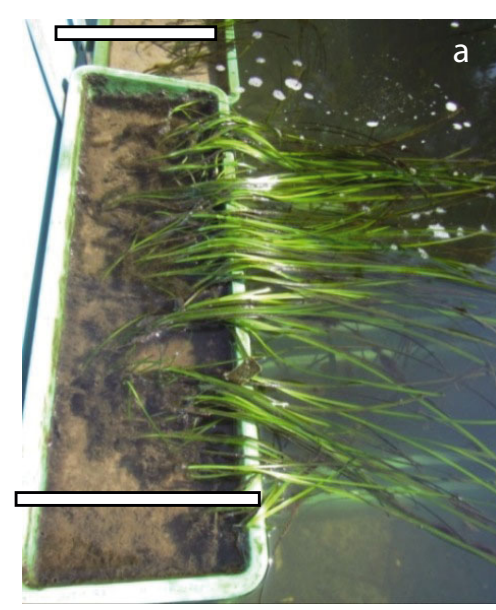

$823 \mu \mathrm{M} \mathrm{CO}_{2(\text { aq) }} \mathrm{pH} 6.5$

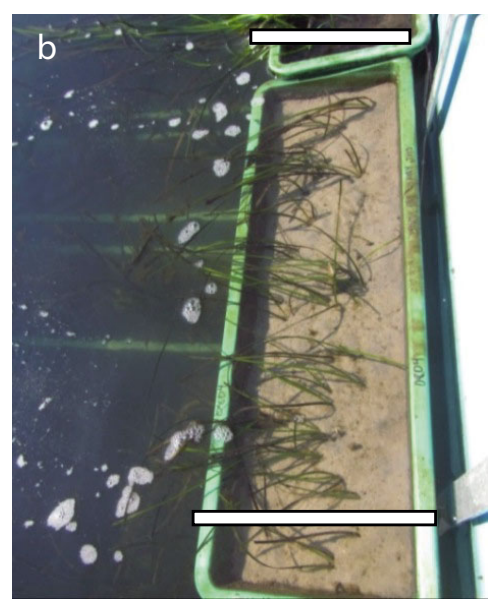

$55 \mu \mathrm{M} \mathrm{CO}_{2 \text { (aq) }} \mathrm{pH} 7.7$ (ambient)

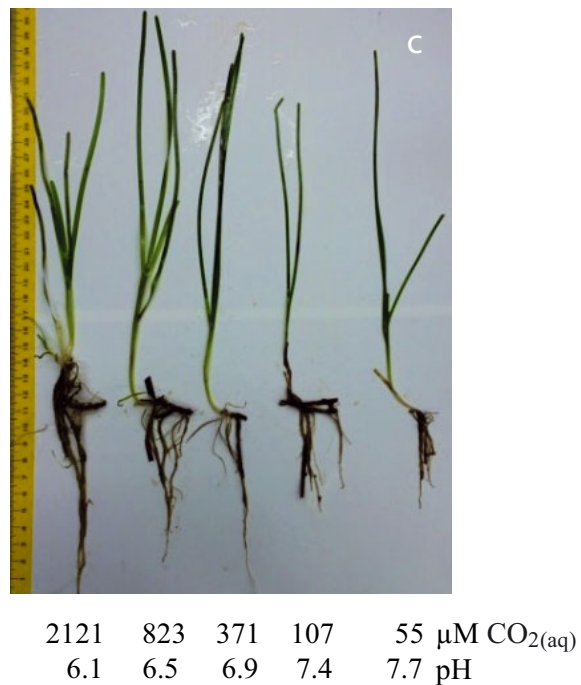

Fig. 6. Eelgrass growing at (a) $823 \mu \mathrm{M} \mathrm{CO}_{2(\mathrm{aq}),} \mathrm{pH} 6.5$ and (b) $55 \mu \mathrm{M} \mathrm{CO}_{2(\mathrm{aq})}, \mathrm{pH} 7.7$ (ambient) after 6 mo growth in the experimental chambers in October 2013. White bars at the top and bottom of the pictures are $20 \mathrm{~cm}$ long. (c) Differences in eelgrass shoot size across the $\mathrm{CO}_{2}$ gradient in October 2014 

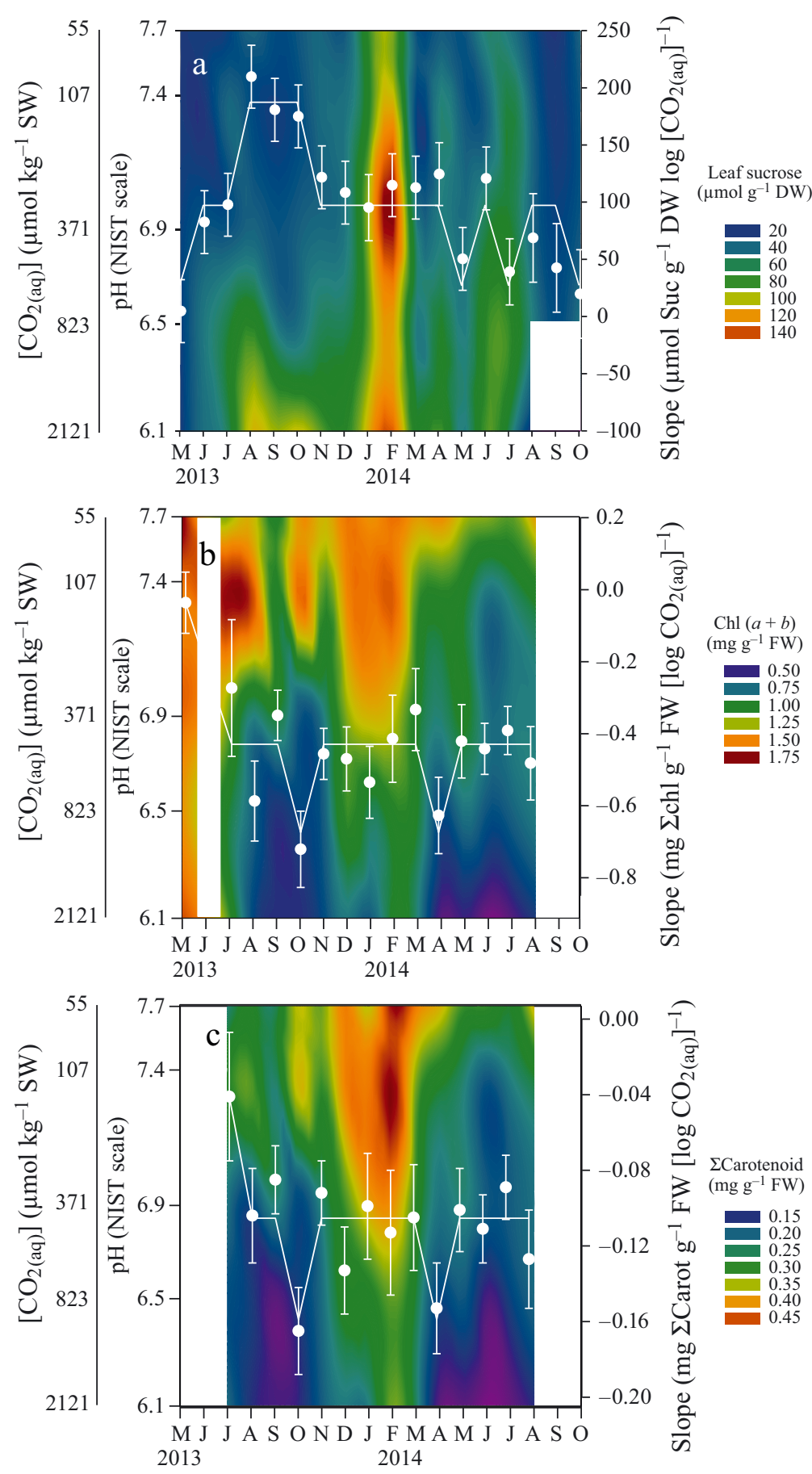

Fig. 7. Heat maps. (a) Leaf sucrose concentration contoured as a function of $\mathrm{CO}_{2 \text { (aq) }}$ treatment and time. (b) Total chlorophyll $(a+b)$ concentration contoured as a function of $\mathrm{pH} / \mathrm{CO}_{2(\mathrm{aq})}$ treatment and time. (c) Total carotenoid concentration contoured as a function of $\mathrm{pH} / \mathrm{CO}_{2(\mathrm{aq})}$ treatment and time. Tick marks on the left vertical axis of each plot indicate the mean $\mathrm{pH} / \mathrm{CO}_{2(\mathrm{aq})}$ value for each treatment. White symbols on each plot represent the slope of the response variable vs. $\log \left[\mathrm{CO}_{2(\mathrm{aq})}\right]$ derived from linear regression analysis. Error bars represent $\pm 1 \mathrm{SE}$ of the regression slope. Horizontal lines indicate slopes that were determined to be statistically identical by ANCOVA post hoc analysis. The white fields indicate no data. DW: dry weight; FW: fresh weight; SW: seawater netic and ecotypic diversity exists throughout eelgrass populations distributed throughout the Northern Hemisphere (Backman 1991, van Lent \& Verschuure 1994, Olsen et al. 2004). In addition, the high organic carbon content of some sedimentary environments may subject seagrasses to increased vulnerability to sulfide anoxia, particularly at elevated temperature (Pedersen et al. 2004, Borum et al. 2005, Govers et al. 2014). However, $\mathrm{CO}_{2}$ stimulation of seagrass photosynthesis generates a proportional increase in belowground release of photosynthetic oxygen from the roots and rhizomes of seagrasses that may also mitigate vulnerability to sulfide intrusion (Bodensteiner 2006).

Sugar signaling has significant impacts on metabolism, growth, stress responses, and development from embryogenesis to senescence, including flowering (Rolland et al. 2006, Springer \& Ward 2007), and provides a mechanism whereby $\left[\mathrm{CO}_{2(\mathrm{aq})}\right]$ can affect the dynamics of flowering shoot production observed here. The onset of flowering in natural eelgrass populations has been reported to occur earlier in the year as latitude decreases and ambient water temperature increases (Phillips et al. 1983). In the California experiment (Palacios \& Zimmerman 2007), flowering shoots first appeared in April in all $\mathrm{CO}_{2}$ treatments, and the flowering process continued throughout the summer. Even though winter water temperature was cooler by $6^{\circ} \mathrm{C}$ in the experiment presented here, flowering shoot initiation began here in January under high $\left[\mathrm{CO}_{2(\mathrm{aq})}\right]$ and was completed by early July in all treatments, nearly 3 mo earlier than observed in the California experiment. Further, the flowering rate observed here (50\% of the shoot population) was nearly double that observed in the prior experiment at high $\left[\mathrm{CO}_{2(\mathrm{aq})}\right]$. Although both experiments were conducted at the same latitude $\left(36.8^{\circ} \mathrm{N}\right)$ and the pattern of incident irradiance was nearly identical at the 2 locations, the light intensity experienced by eelgrass in the California experiment $33 \%$ of surface irradiance) was half that used here. This difference in the daily pattern of light intensity may also be responsible for the higher flowering rates $(50 \%$ of the shoot population at high $\left.\left[\mathrm{CO}_{2(\mathrm{aq})}\right]\right)$ observed here relative to the California experiment $\left(25 \%\right.$ at high $\left.\left[\mathrm{CO}_{2(\mathrm{aq})}\right]\right)$. 
Nonetheless, the rates of flowering observed under elevated $\left[\mathrm{CO}_{2(\mathrm{aq})}\right]$ in both experiments were 3 to 5 times higher than the $10 \%$ levels typically observed in natural populations (Hemminga \& Duarte 2000). Taken together, these results suggest that sugar accumulation may be critical in regulating the flowering process in eelgrass, while the direct effects of temperature are of secondary importance.

Sucrose accumulation resulting from elevated $\mathrm{CO}_{2}$ availability can also result in the down-regulation of light-saturated photosynthetic capacity via expression of the Rubisco small subunit (Moore et al. 1999, Walters 2005). However, there was no significant downregulation of pigment-specific photosynthetic capacity during the course of this experiment (Celebi 2016). Instead, the down-regulation of leaf pigment content under high $\left[\mathrm{CO}_{2(\mathrm{aq})}\right]$ observed here suggests that elevated $\mathrm{CO}_{2}$ availability may be triggering photoacclimation mechanisms sensitive to the redox state of the electron transport chain and/or the production of reactive oxygen species resulting from $\mathrm{CO}_{2}$-stimulated photosynthetic activity (Pfannschmidt et al. 2009).

Taken together, the experimental results presented here demonstrate that $\mathrm{CO}_{2}$ availability can affect the temperature tolerance, vegetative growth, and flowering effort of Chesapeake region eelgrass via its impact on photosynthetic carbon fixation, sugar accumulation, and metabolic carbon balance. These results support previous model simulations that increased $\mathrm{CO}_{2}$ availability associated with climate change may permit the survival of eelgrass in the Chesapeake region in spite of a warming climate (Zimmerman et al. 2015). Although it can be difficult to extrapolate the results of carefully controlled aquarium studies to the performance of organisms in the field, the experimental system employed here captured the full suite of natural estuarine variability in ambient temperature, solar irradiation, salinity, alkalinity and $\mathrm{pH}$, strengthening our confidence in the reality of the responses observed here. However, even these aquarium experiments fall short of the ecosystem-level realism afforded by free-air $\mathrm{CO}_{2}$ experiments (Ainsworth \& Long 2005, Leakey et al. 2009). The technology to perform similar free-ocean $\mathrm{CO}_{2}$ experiments is improving, but many challenges remain to its successful implementation, particularly for long-term, multifactor experiments (Gattuso et al. 2014). In the meantime, progress in understanding the impacts of climate change on marine ecosystems is likely to depend heavily on a combination of controlled experiments, numerical modeling, and field observations capable of integrating natural variability and scaling the results across time and space (Andersson et al. 2015).
Acknowledgements. Thanks to Christopher M. Powell (ODU) for assistance with LabView programming and integration of the CTD into the environmental monitoring system and to Sean Bourgeois and Charles Jourdant (Virginia Aquarium) for construction and operational maintenance of the water intake system during the experiment. Financial support for this research was provided by the National Science Foundation (Award OCE-1061823) and Virginia Sea Grant/NOAA (Award NA10OAR4170085).

\section{LITERATURE CITED}

Ainsworth EA, Long SP (2005) What have we learned from 15 years of free-air $\mathrm{CO}_{2}$ enrichment (FACE)? A metaanalytic review of the responses of photosynthesis, canopy properties and plant production to rising $\mathrm{CO}_{2}$. New Phytol 165:351-372

Andersson AJ, Kline DI, Edmunds PJ, Archer SD and others (2015) Understanding ocean acidification impacts on organismal to ecological scales. Oceanography 28:16-27

*Backman TWH (1991) Genotypic and phenotypic variability of Zostera marina on the west coast of North America. Can J Bot 69:1361-1371

Beer S (1994) Mechanisms of inorganic carbon acquisition in marine macroalgae (with special reference to the Chlorophyta). Prog Phycol Res 10:179-207

Beer S, Eschel A, Waisel Y (1977) Carbon metabolism in seagrasses: I. The utilization of exogenous inorganic carbon species in photosynthesis. J Exp Bot 28:1180-1189

* Bergmann N, Winters G, Rauch G, Eizaguirre C and others (2010) Population-specificity of heat stress gene induction in northern and southern eelgrass Zostera marina populations under simulated global warming. Mol Ecol 19:2870-2883

Bodensteiner LE (2006) The impact of light availability on benthic oxygen release by the seagrasses Thalassia testudinum (Banks ex König) and Zostera marina L. MS thesis, San Jose State University, CA

Borum J, Pedersen O, Greve TM, Frankovich TA, Zieman JC, Fourqurean JW, Madden CJ (2005) The potential role of plant oxygen and sulphide dynamics in die-off events of the tropical seagrass, Thalassia testudinum. J Ecol 93:148-158

*Bun FG, Hernández I, Vergara JJ, Peralta G, Pérez-Lloréns JL (2002) Assessing the toxicity of ammonium pulses to the survival and growth of Zostera noltii. Mar Ecol Prog Ser 225:177-187

Burkholder JM, Mason KM, Glasgow HB Jr (1992) Watercolumn nitrate enrichment promotes decline of eelgrass Zostera marina: evidence from seasonal mesocosm experiments. Mar Ecol Prog Ser 81:163-178

Campbell JE, Fourqurean JW (2013) Effects of in situ $\mathrm{CO}_{2}$ enrichment on the structural and chemical characteristics of the seagrass Thalassia testudinum. Mar Biol 160: 1465-1475

Celebi B (2016) Potential impacts of climate change on photochemistry of Zostera marina L. PhD thesis, Old Dominion University, Norfolk, VA

Cleland EE, Chuine I, Menzel A, Mooney HA, Schwartz MD (2007) Shifting plant phenology in response to global change. Trends Ecol Evol 22:357-365

Dlugokencky E, Tans P (2016) Recent global $\mathrm{CO}_{2}$. www.esrl. noaa.gov/gmd/ccgg/trends/global.html (accessed 12 Dec 2016) 
Duarte CM, Hendricks IE, Moore TS, Olsen YS and others (2013) Is ocean acidification an open-ocean syndrome? Understanding the drivers and impacts of $\mathrm{pH}$ variability in coastal ecosystems. Estuaries Coasts 36:221-236

Durako MJ (1993) Photosynthetic utilization of $\mathrm{CO}_{2(\mathrm{aq})}$ and $\mathrm{HCO}_{3}{ }^{-}$in Thalassia testudinum (Hydrocharitacae). Mar Biol 115:373-380

Ehlers A, Worm B, Reusch TBH (2008) Importance of genetic diversity in eelgrass Zostera marina for its resilience to global warming. Mar Ecol Prog Ser 355:1-7

Evans AS, Webb KL, Penhale PA (1986) Photosynthetic temperature acclimation in two coexisting seagrasses, Zostera marina L. and Ruppia maritima L. Aquat Bot 24: 185-197

Fabry VJ, Langdon C, Balch WM, Dickson AG and others (2008) Present and future impacts of ocean acidification on marine ecosystems and biogeochemical cycles. Report of the Ocean Carbon and Biogeochemistry Scoping Workshop on Ocean Acidification Research, 9-11 October 2007, La Jolla, CA, sponsored by the US Ocean Carbon and Biogeochemistry Program with support from NSF, NOAA and NASA

* Gattuso JP, Kirkwood W, Barry JP, Cox E and others (2014) Free-ocean $\mathrm{CO}_{2}$ enrichment (FOCE) systems: present status and future developments. Biogeosciences 11: 4057-4072

Gieskes JM, Rodgers WC (1973) Alkalinity determination in interstitial waters of marine sediments. J Sediment Res 43:272-277

Govers LL, de Brouwer JHF, Suykerbuyk W, Bouma TJ, Lamers LPM, Smolders AJP, van Katwijk MM (2014) Toxic effects of increased sediment nutrient and organic matter loading on the seagrass Zostera noltii. Aquat Toxicol 155:253-260

Hall-Spencer JM, Rodolfo-Metalpa R, Martin S, Ransome E and others (2008) Volcanic carbon dioxide vents show ecosystem effects of ocean acidification. Nature 454: 96-99

Hemminga MA, Duarte CM (2000) Seagrass ecology. Cambridge University Press, Cambridge

*Huber SC, Israel DW (1982) Biochemical basis for partitioning of photosynthetically fixed carbon between starch and sucrose in soybean (Glycine max Merr.) leaves. Plant Physiol 69:691-696

Hutchins DA, Fu FX, Zhang Y, Warner ME and others (2007) $\mathrm{CO}_{2}$ control of Trichodesmium $\mathrm{N}_{2}$ fixation, photosynthesis, growth rates, and elemental ratios: implications for past, present, and future ocean biogeochemistry. Limnol Oceanogr 52:1293-1304

次 Invers O, Zimmerman RC, Alberte RS, Perez M, Romero J (2001) Inorganic carbon sources for seagrass photosynthesis: an experimental evaluation for bicarbonate use in temperate species. J Exp Mar Biol Ecol 265:203-217

IPCC (Intergovernmental Panel on Climate Change) (2013) Climate change 2013: the physical science basis. Contribution of Working Group I to the Fifth Assessment Report of the Intergovernmental Panel on Climate Change. Cambridge University Press, New York, NY

Jarvis JC, Moore KA, Kenworthy WJ (2012) Characterization and ecological implication of eelgrass life history strategies near the species' southern limit in the western North Atlantic. Mar Ecol Prog Ser 444:43-56

Jiang ZJ, Huang XP, Zhang JP (2010) Effects of $\mathrm{CO}_{2}$ enrichment on photosynthesis, growth and biochemical composition of seagrass Thalassia hemprechii (Ehrenb.)
Aschers. J Integr Plant Biol 52:904-913

Kleypas JA, Buddemeier RW, Archer D, Gattuso JP, Langdon C, Opdyke BN (1999) Geochemical consequences of increased atmospheric carbon dioxide on coral reefs. Science 284:118-120

Kleypas JA, Feeley RA, Fabry VJ, Langdon C, Sabine CL, Robbins LL (2006) Impacts of ocean acidification on coral reefs and other marine calcifiers: a guide for future research. Report of a workshop held 18-20 April 2005, St. Petersburg, FL, sponsored by NSF, NOAA and US Geol Surv

* Leakey ADB, Ainsworth EA, Bernacchi CJ, Rogers A, Long $\mathrm{SP}$, Ort DR (2009) Elevated $\mathrm{CO}_{2}$ effects on plant carbon, nitrogen, and water relations: six important lessons from FACE. J Exp Bot 60:2859-2876

Lewis EL (1980) The practical salinity scale 1978 and its antecedents. IEEE J Oceanic Eng OE-5:3-8

Lewis E, Wallace D (1998) Program developed for $\mathrm{CO}_{2}$ system calculations. Carbon Dioxide Information Analysis Center, Oak Ridge National Laboratory, US Dept Energy, ORNL/CDIAC-105, Oak Ridge, TN

* Lichtenthaler HT, Wellburn AR (1983) Determinations of total carotenoids and chlorophylls $a$ and $b$ of leaf extracts in different solvents. Biochem Soc Trans 11:591-592

* Mackey KRM, Morris JJ, Morel FMM, Kranz SA (2015) Response of photosynthesis to ocean acidification. Oceanography 28:74-91

*McLeod E, Chmura GL, Bouillon S, Salm R and others (2011) A blueprint for blue carbon: toward an improved understanding of the role of vegetated coastal habitats in sequestering $\mathrm{CO}_{2}$. Front Ecol Environ 9:552-560

*Moore KA, Jarvis JC (2008) Environmental factors affecting summertime eelgrass diebacks in the lower Chesapeake Bay: implications for long-term persistence. J Coast Res 55(Spec Iss):135-147

* Moore BD, Cheng SH, Sims D, Seemann JR (1999) The biochemical and molecular basis for photosynthetic acclimation to elevated atmospheric $\mathrm{CO}_{2}$. Plant Cell Environ 22:567-582

Moore KA, Shields EC, Parrish DB, Orth RJ (2012) Eelgrass survival in two contrasting systems: role of turbidity and summer water temperatures. Mar Ecol Prog Ser 448: $247-258$

* Olsen JL, Stam WT, Coyer JA, Reusch TBH and others (2004) North Atlantic phylogeography and large-scale population differentiation of the seagrass Zostera marina L. Mol Ecol 13:1923-1941

\% Orth RJ, Moore KA (1983) Chesapeake Bay: an unprecedented decline in submerged aquatic vegetation. Science 222:51-53

Orth RJ, Carruthers TBJ, Dennison WC, Duarte CM and others (2006) A global crisis for seagrass ecosystems. Bioscience 56:987-996

* Orth RJ, Marion SR, Moore KA, Wilcox DJ (2010) Eelgrass (Zostera marina L.) in the Chesapeake Bay region of mid-Atlantic coast of the USA: challenges in conservation and restoration. Estuaries Coasts 33:139-150

*Palacios SL, Zimmerman RC (2007) Response of eelgrass Zostera marina to $\mathrm{CO}_{2}$ enrichment: possible impacts of climate change and potential for remediation of coastal habitats. Mar Ecol Prog Ser 344:1-13

* Pearson PN, Palmer MR (2000) Atmospheric carbon dioxide concentrations over the past 60 million years. Nature 406:695-699

Pedersen O, Binzer T, Borum J (2004) Sulphide intrusion in 
eelgrass (Zostera marina L.). Plant Cell Environ 27: 595-602

Pfannschmidt T, Bräutigam K, Wagner R, Dietzel L, Schröter Y, Steiner S, Nykytenko A (2009) Potential regulation of gene expression in photosynthetic cells by redox and energy state: approaches toward better understanding. Ann Bot 103:599-607

Phillips RC, Grant WS, McRoy CP (1983) Reproductive strategies of eelgrass (Zostera marina L.). Aquat Bot 16: $1-20$

Rivero-Calle S, Gnandesikian A, Del Castillo CE, Balch WM, Guikema SD (2015) Multidecadal increase in North Atlantic coccolithophores and the potential role of rising $\mathrm{CO}_{2}$. Science 350:1533-1537

Rolland F, Baena-Gonzalez E, Sheen J (2006) Sugar sensing and signaling in plants: conserved and novel mechanisms. Annu Rev Plant Biol 57:675-709

Ruesink JL, Yang S, Trimble AC (2015) Variability in carbon availability and eelgrass (Zostera marina) biometrics along an estuarine gradient in Willapa Bay, WA, USA. Estuaries Coasts 38:1908-1917

Sisson M, Shen J, Reay W, Miles E, Kuo A, Wang H (2010) The development of a management tool to assess bacterial impacts in Rudee Inlet, Virginia Beach. Spec Rep No. 423, Virginia Institute of Marine Science, Gloucester Point, VA

Springer CJ, Ward JK (2007) Flowering time and elevated atmospheric $\mathrm{CO}_{2}$. New Phytol 176:243-255

*van der Heide T, Smolders AJP, Rijkens BGA, van Nes EH, van Katwijk MM, Roelofs JGM (2008) Toxicity of reduced nitrogen in eelgrass (Zostera marina) is highly dependent on shoot density and $\mathrm{pH}$. Oecologia 158:411-419

van Lent F, Verschuure JM (1994) Intraspecific variability of Zostera marina L. (eelgrass) in the estuaries and lagoons of the southwestern Netherlands. I. Population dynamics. Aquat Bot 48:31-58

Waldbusser GG, Salisbury JE (2014) Ocean acidification in

Editorial responsibility: Morten Pedersen,

Roskilde, Denmark the coastal zone from an organism's perspective: multiple system parameters, frequency domains and habitats. Annu Rev Mar Sci 6:221-247

*Walters RG (2005) Towards an understanding of photosynthetic acclimation. J Exp Bot 56:435-447

Walther GR, Post E, Convey P, Menzel A and others (2002) Ecological responses to recent climate change. Nature 416:389-395

Winters G, Nelle P, Fricke B, Rauch G, Reusch TBH (2011) Effects of a simulated heat wave on photophysiology and gene expression of high- and low-latitude populations of Zostera marina. Mar Ecol Prog Ser 435:83-95

Zieman JC (1974) Methods for the study of the growth and production of turtle grass, Thalassia testudinum König. Aquaculture 4:139-143

Zimmerman RC, Smith RD, Alberte RS (1987) Is growth of eelgrass nitrogen limited? A numerical simulation of the effects of light and nitrogen on the growth dynamics of Zostera marina. Mar Ecol Prog Ser 41:167-176

Kimmerman RC, Smith RD, Alberte RS (1989) Thermal acclimation and whole plant carbon balance in Zostera marina L. (eelgrass). J Exp Mar Biol Ecol 130:93-109

Zimmerman RC, Kohrs DG, Steller DL, Alberte RS (1995) Carbon partitioning in eelgrass (regulation by photosynthesis and the response to daily light-dark cycles). Plant Physiol 108:1665-1671

Zimmerman RC, Kohrs DG, Alberte RS (1996) Top-down impact through a bottom-up mechanism: the effect of limpet grazing on growth, productivity and carbon allocation of Zostera marina. Oecologia 107:560-567

* Zimmerman RC, Kohrs DG, Steller DL, Alberte RS (1997) Impacts of $\mathrm{CO}_{2}$ enrichment on productivity and light requirements of eelgrass. Plant Physiol 115:599-607

* Zimmerman RC, Hill VJ, Gallegos CL (2015) Predicting effects of ocean warming, acidification and water quality on Chesapeake region eelgrass. Limnol Oceanogr 60: 1781-1804

Submitted: August 19, 2016; Accepted: January 8, 2017 Proofs received from author(s): February 12, 2017 